CORRECTION

\title{
Correction to: Campylobacter infection promotes IFNY- dependent intestinal pathology via ILC3 to ILC1 conversion
}

Wayne T. Muraoka, Anna A. Korchagina, Qingqing Xia, Sergey A. Shein, Xi Jing, Zhao Lai, Korri S. Weldon, Li-Ju Wang, Yidong Chen, Lawrence W. Kummer, Markus Mohrs, Eric Vivier, Ekaterina P. Koroleva and Alexei V. Tumanov (iD)

(C) Society for Mucosal Immunology 2021

Mucosal Immunology (2021) 14:1397; https://doi.org/10.1038/s41385-021-00449-9

Correction to: Mucosal Immunology https://doi.org/10.1038/ s41385-020-00353-8, published online 19 November 2020
Figure 3 panel $\mathrm{g}$ was accidentally overlayed onto panel $\mathrm{h}$ during layout formatting of accepted paper. The original version has been corrected. a

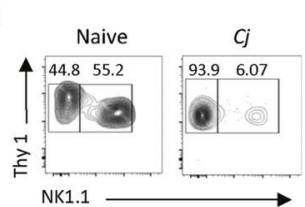

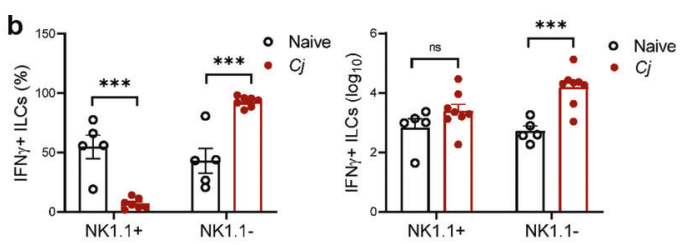

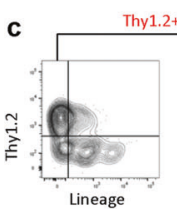

Thy1.2+Lin-
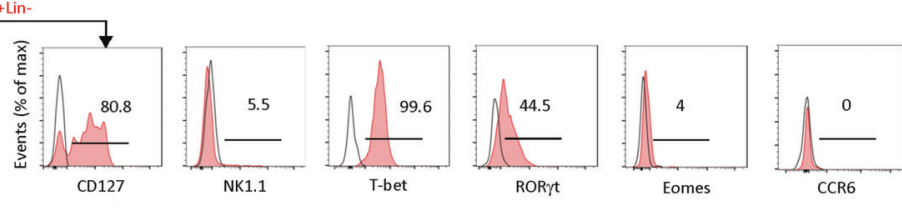

IFN $Y^{+}$CD3- Lin ${ }^{-}$Thy $1.2^{+}$gated

d
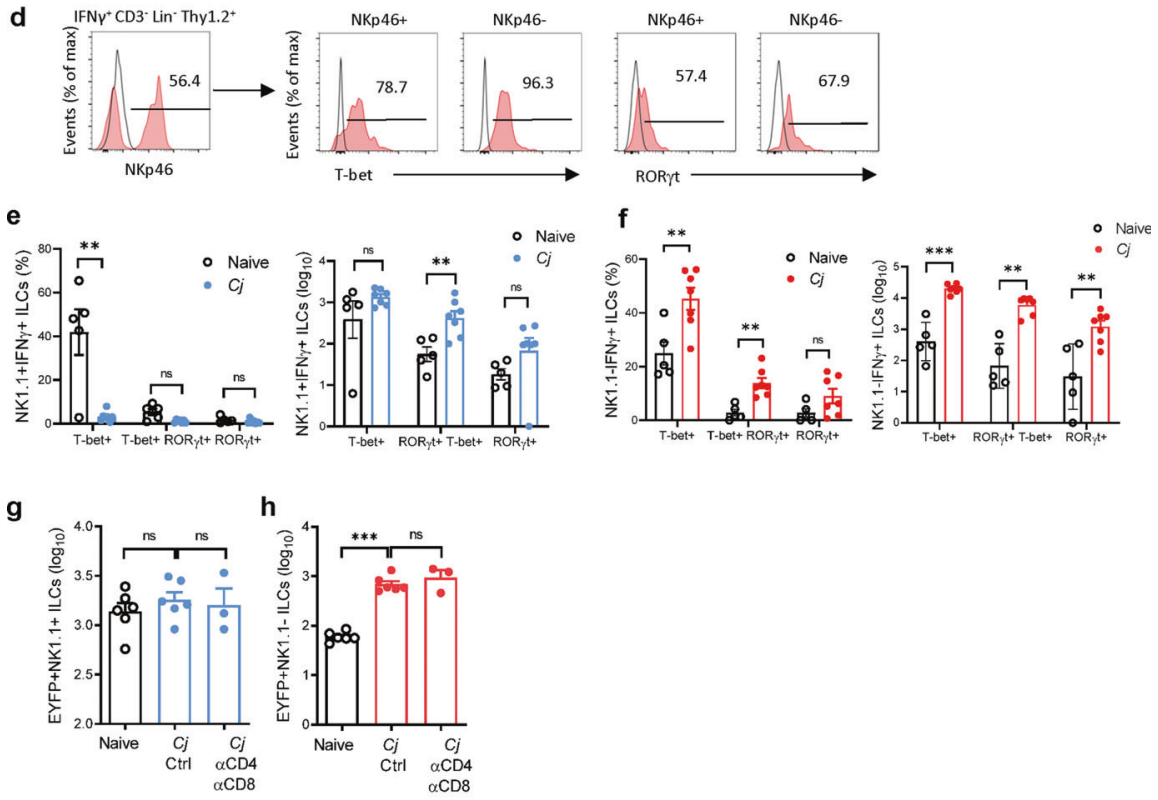

h

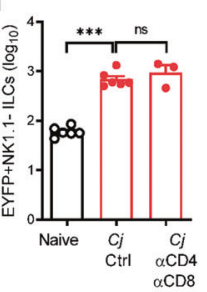

Cells/cecum $\left(\log _{10}\right)$ IFNץ reporter 